\title{
COMPARISON OF REGULATORY MODELS OF HIGHER EDUCATION IN EUROPE. THE PORTUGUESE SITUATION
}

\author{
Pedro Rei Bernardino * \\ Rui Cunha Marques **
}

Recebido em: 05 de agosto de 2008

Aprovado em: 12 de dezembro de 2008

\begin{abstract}
* Pedro Bernardino, Center for Urban and Regional Systems (CESUR), DECivil-IST, Technical University of Lisbon, Beco do Rio Cabo, n. ${ }^{\circ} 12$, Amiais de Baixo, 2025-307, Portugal. E-mail: pedro9rei@gmail.com

** Rui Cunha Marques, Center for Urban and Regional Systems, (CESUR), DECivil-IST, Technical University of Lisbon, Av. Rovisco Pais, 1049-001 Lisbon, Portugal. E-mail: rcmar@civil.ist.utl.pt
\end{abstract}

\begin{abstract}
The regulation of Portuguese Higher Education is now in a period of evolution and undergoing profound changes. The quality assurance system implemented was criticised from the beginning, raising many doubts, and was often associated with some weaknesses. The pressure put on the Portuguese government to meet quality assurance standards in the scope of European Higher Education is enormous and several reforms and policy developments show that Portugal's Higher Education system is on the move. This paper compares the regulatory models in other European countries and analyses the new Portuguese model.
\end{abstract}

Key words: Higher education. Quality assurance. Portugal. Regulatory agency.

Resumo: A regulação do ensino superior em Portugal está a atravessar um periodo de crescimento de profundas alterações. O sistema de garantia de qualidade implementado anteriormente foi criticado desde o seu começo, levantando muitas dúvidas e frequentemente associado a várias fraquezas. A pressão colocada no governo Português para atingir padrões de garantia de qualidade em conformidade com os padrões Europeus é enorme e várias reformas e politicas mostram que o sistema do ensino superior em Portugal está em movimento. Este artigo compara vários modelos de regulação de outros países Europeus e analisa o modelo Português.

Palavras chave: Ensino superior. Garantia de qualidade. Portugal. Agencia reguladora.

\section{Introduction}

The Bologna Declaration in 1999 established the creation of a European Higher Education Area by 2010. This commitment brought forward many discussions about the regulatory models of Higher Education and how they improve quality of the Higher Education Institutions. Portugal is at this moment creating a new regulatory model. In this paper we look at other European regulatory systems and bring about some ideas for the Portuguese system. 
We present the Dutch, Spanish and English regulatory models and compare them with the Portuguese recent reforms. Some policy conclusions are presented.

\section{Regulation of the Quality of Higher Education in EUROPE}

\subsection{Holland}

The Dutch higher education system is binary and consists of research universities and universities of professional education. They can be either public or private. In the Netherlands everyone is free to establish an educational institution and to offer course programmes. Because of this there are numerous private institutions that were not founded and maintained by the state. However, many private institutions have been given recognition by the government. (CPC, NETHERLANDS BUREAU FOR ECONOMICS, 2002)

Since 2000 the Netherlands and Flanders intend to establish a joint accreditation organization that would be in change of the accreditation of higher education programmes. In 2000, with the creation of the Netherlands Accreditation Organization (NAO), the first step was taken and finally three years later, in 2003, the two governments signed the treaty for the establishment of the Accreditation Organization of the Netherlands and Flanders (NVAO). Both Netherlands and Flanders had already external review systems before NVAO, but with the introduction of the new system efforts have been made to strengthen the former model of external review and to make it internationally more acceptable. The main purpose of NVAO is the accreditation of programmes of higher education and to give advice on the possible extension of academically oriented master programmes, including the research masters. The accreditation system is three tiered: the first tier is the institution, the second is the external quality assessment agency and finally NVAO is the third tier. (ENQA, 2007)

The accreditation process is divided into three steps. The first step is the self-evaluation report. This report is not public and is not included in the accreditation report. It should contain self-critical and reflective aspects in a way that the panel may be able to form balanced judgements. The second step is the external assessment, the evaluation panel should be composed by experts in specific areas and always have members from the students. Finally, the last step is the accreditation decision. If the decision is negative the institution will be granted an improvement period and it can appeal against the initial 
decision taken by NVAO. If a programme receives accreditation it means that the institution is entitled to award recognized diplomas and degrees for that programme for the next six years and that students may obtain a student grant and a student loan while enrolled on that programme. Furthermore, government-funded institutions receive funding in respect of their accredited study programmes. (FABER; HUISMAN, 2003)

In brief, we can distinguish three categories for the Dutch educational institutions (ENQA, 2007):

Government funded institutions - they are entitled to award officially recognized degrees and legally protected titles for their accredited programmes. Students may apply for student grants and/or a student loan if they follow an accredited programme of study at a government-funded institution. To obtain government funding, institutions must satisfy a number of quality requirements. This number is fairly stable and only rarely there are changes in the group of government-funded institutions.

Government-approved institutions - the government approval is the official recognition of the quality of private educational institutions. This form of approval gives institutions certain benefits. For example, government-approved institutions have the same entitlement as government-funded institutions to award officially recognized diplomas and legally protected titles for their accredited programmes. Likewise, their students may apply for a student grant and/or a student loan. A private institution seeking government approval must submit an application to the Ministry of Education. With this application they send the judgment to the NVAO.

Institutions without government funding or approval - the quality of these institutions has not been approved by the government, and they do not receive any funding from the government. The fact that an institution is not governmentfunded or approved does not automatically mean that the quality it provides is below par: there are many organizations in the Netherlands that provide quality assurance services, but they are not officially recognized by the government.

The consequences of a negative accreditation decision are different in the Netherlands and in Flanders. In Flanders the institutions have an improvement plan for the programme and three years later they can submit a new application for accreditation. In the Netherlands consequences are harsher, they also have an improvement plan, but as long the programme is not accredited the institution will not receive public funds and cannot enrol new students. 
The Netherlands does not have any official ranking system for study programmes or educational institutions, but the assessment agency uses a grading process for their assessment of standards listed in the assessment framework. The grades are descriptive and include four points: "excellent”, "good”, "satisfactory" and "unsatisfactory". In order that the programme receives a positive final assessment the agency panel must award each theme with a satisfactory score. A positive decision can only be based on positive judgements of the themes in the assessment framework. The assessment of a theme in the framework is done on the basis of the assessments of separate standards leading to the conclusion concerning that theme. In other words, the panel has to clarify how the assessment of a theme is based on the assessment of the underlying standards. (NVAO, 2003)

The assessment framework consists of six themes, each one with corresponding standards, and every standard has its own criteria. The themes and standards of NVAO are (NVAO, 2003):

\section{Aims and Objectives}

a. Subject-/Discipline-specific requirements

b. Bachelor and master level

c. Professional orientation / academic orientation

d. Requirements for professional / academic orientation

2. Curriculum
a. Requirements for professional / academic orientation
b. Correspondence between the aims and objectives and the cur- riculum
c. Consistency of the curriculum
d. Workload
e. Admissions requirements
f. Credits
g. Coherence of structure and contents
h. Learning assessment

\section{Staff}
a. Requirements for professional/academic orientation
b. Quantity of staff
c. Quality of staff

\section{Services
a. Facilities
b. Tutoring

5. Internal Quality Assurance System

a. Periodical evaluations 
b. Measures for improvement

c. Involvement of staff, students and the professional field

6. Results

a. Achieved learning outcomes

b. Study progress

\subsection{Spain}

With the Bologna Declaration in 1999 the European Ministers of Education signed a commitment to establish the European Higher Education Area by 2010, the Spanish minister included. Therefore the parliament reformed the legislation and passed the Spanish Universities Act that aim at structuring and bringing together the university system by strengthening relations between university and society and especially improving the quality of teaching, research and management. The new law was an enormous step to the new quality assurance system in Spain. The article 32 of Organic Law 6/2001 authorised the establishment of the National Agency for Quality Assessment and Accreditation (ANECA) which was set up as a public trust by the Spanish Ministry of Education and Science on 19 July 2002. However, the law doesn't specify any regulation about the process of evaluation to apply by the new quality agency which leads to a commitment by the governing bodies of ANECA to organise the process of evaluation on the quality in higher education in accordance with the Standards and Guidelines for Quality Assurance (ESG) in the European Higher Education Area. (ENQA, 2006)

The Spanish higher education quality assurance system is composed by three national agencies, the National Agency for the Quality Assessment and Accreditation, "Agencia Nacional de Evaluación de la Calidad y Acreditación”, (ANECA), the National Research Assessment Commission, "Consejo Nacional de Evaluación y de la Investigación” (CNEAI) and the National Evaluation and Planning Agency, “Agencia Nacional de Evaluación y Planificación” (ANEP). The main role of ANECA is to monitor by means of evaluation the promotion and quality of both private and public universities and their integration on the European Higher Education Area, the Spanish system has also 11 regional agencies for quality evaluation. (ENQA, 2006)

The Spanish agency ANECA is a relatively young organisation. It only started working about six years ago and for that reason some of their evaluation programmes are new and have never been done before. ANECA has a crucial role in the Spanish quality assurance system and performs it using several evaluation programmes. 
The Institutional Assessment programme assesses degrees rather than institutions, and was created with the main purpose of improving quality of the educational programmes through an improvement plan as the result of the evaluation with public criteria, identifying the main strengths and weaknesses.

The Quality Label Recognition programme has the objective of recognizing the scientific, technical and educational credibility of the doctoral programmes and also the groups that carry out the doctoral studies.

Recognised postgraduate programmes evaluation became operational in 2006, and it aimed to evaluate proposals for postgraduate degrees in universities in Autonomous Communities that do have an evaluation agency.

Library Services evaluation programmes have the responsibility of evaluating university library service, providing an improvement plan.

Library services quality certification programme confers recognition of university library services as consequence of an evaluation process.

University Services Evaluation Programme was launched in 2006 and helps the universities to improve their services and management units based on the European Foundation for Quality Management model.

Teaching Staff assessment programmes for recruitment purposes guarantees that the minimum standards are fulfilled by applicants for positions as contracted teaching staff at public and private universities.

Teaching activity assessment support programme aims to provide a model of guidance for the universities to design their own models and procedures for evaluating teaching activity and teaching staff.

ANECA is at this point launching new programmes of assessment, whose objectives are to improve the quality of the Spanish higher education and enlarge its own role in the quality assurance system. The new programmes are:

The AUDIT programme that seeks to provide guidance to institutions in designing quality assurance systems for university studies and to implement an evaluation procedure that leads to the recognition of the design.

The VERIFICA programme objective is to verify the conformity of proposals for new curricula with the guidelines that structure new undergraduates and master degrees.

The ACREDITA programme has the main objective of establishing standards and guidelines for the accreditation of recognised undergraduate and master degrees.

The TRAINING programme aims to provide a set of instruments and evaluation indicators for units in charge of training plans that wish to be evaluated as a stimulus for improvement. 
The objectives of the institutional assessment programme is to facilitate an evaluation process to officially improve the quality of education leading to obtain university degrees through the territory of Spain and, at the same time, provide information about the study programmes to the students, families and society, to the government bodies of the universities and to the public administration.

The process of institutional assessment is divided into three phases. The first one is the self-assessment report that should identify the main strengths and weaknesses of the programme, and also describe and evaluate the situation of the assessed degree with respect to the criteria established. The second phase is the external assessment by a group of external assessors to the teaching staff of the university, appointed by ANECA and their function is to analyse the self-assessment report and through visits evaluate the programme and then report the main issues and recommendations. The last step is a plan of improvement. This phase concludes with the plan for improvements of the educational programme where the tasks to be accomplished are decided as well the people responsible for them, the resources involved and the deadlines for their implementation. Similarly the indicators to monitor the actions proposed and the benefits expected from them are identified (ANECA, 2006).

The criteria used in the institutional assessment programme are divided in themes. Each theme is then split into criteria and then into sub-criteria to facilitate the evaluation. The scale used to evaluate the sub-criteria has four points: A - "excellent”, B - "Good", C - "satisfactory" and C - "unsatisfactory". With this scale for the sub-criteria the institutions will exactly know what they are doing right and which areas they need to improve in their programmes. The themes and the criteria used in the institutional assessment programme are (ANECA, 2006):

1. Educational Programme

a. Aims of the educational programme

b. Studies plan and its structure

2. Teaching Organisation

a. Management and planning

b. Management and organization

3. Human Resources

a. Academic staff

b. Academic staff and services 
4. Material Resources
a. Classrooms
b. Work spaces
c. Laboratories, workshops and experimental spaces
d. Library and document banks

5. Educational Process

a. Student assistance and integral training

b. Teaching-Learning process

6. Results

a. Results of the educational programme

b. Graduate results

c. Academic staff results

d. Results in society

\section{United Kingdom}

The United Kingdom Higher Education has been subject to rigorous quality evaluations for a long time. These evaluations ensure that it offers high standards of teaching and learning as well as research. But in the last decades the stakeholders demand more from the higher education institutions, especially the government arguing that the public investment in higher education justifies closer scrutiny of the outcomes achieved by public funded institutions and from students who expect to receive good quality teaching and sufficient learning resources to meet their needs. (GOSLING; D’ANDREA, 2001)

Previously, there were two government bodies that carried out the assessments, but they employed different criteria and scales of measurement. They were the Higher Education Funding Councils for England, Scotland and Wales, respectively (HEFCE, SHEFC, HEFCW) and the Higher Education Quality Council (HEQC). The main purpose of quality assessment were to ensure that the public funding provided was supporting education of acceptable quality, to provide public information on that education through the publication of reports and to provide information and insights to encourage improvements in education. (KANJI; MALEK; TAMBI, 1999)

In 1997 the Quality Assurance Agency (QAA) was established to provide an integrated quality assurance service for the UK higher education, replacing the HEQC. The agency is an independent body funded by subscriptions from universities and colleges of higher education, and through contracts with the 
main higher education funding bodies (QAA, 2003). It is the agency's role to provide public assurance that standards and quality within higher education are being safeguarded and enhanced. This is done mainly through a peer review process of audits and reviews. These are conducted by teams of auditors and reviewers, most of them academics. They have four activities (QAA, 2003):

Institutional audit - ensures that the institutions, on the one hand, provide higher education degrees, awards and qualifications with minimum quality and with the appropriate academic standards and, on the other hand, when relevant, exercise their legal powers to award degrees in a proper manner.

Development engagements - aim that the institutions test their internal review process at the level of the discipline programme, and also the robustness of the evidence they use in those procedures.

Academic review - the objective is to evaluate the academic programmes of the higher education institutions and express their confidence in the academic standards.

Major review of NHS-funded healthcare programmes - the department of health care, in partnership with the nursing and Midwifery Council, the health professions council and the workforce development confederations, has contracted with the agency to carry out reviews of all national health services (NHS).

The process of institutional audit in England has been developed by the QAA in cooperation with the HEFCE. The audit teams will focus their evaluation on six specific areas, listed below. To which area the audit team makes a judgement, not about the academic standards but about the way the institution ensures that its academic standards are being secured (QAA, 2006). If the audit verifies that the institution is managing the assurance of academic standards soundly and effectively the judgement will be expressed as "confidence". When the audit team has substantial doubts about the current, or future, management of security of academic standards the judgment will be expressed as "limited confidence". It is not a judgment of failure but indicates that improvements need to be made (QAA, 2006). Finally if the audit team has serious concerns about the capacity of the institution to secure academic standards, the judgement will be "no confidence", which means that the evaluation of the institution is unsatisfactory. These cases are very rare in the UK system but when they occur all stakeholders know about them.

The specific areas evaluated by the audit team are (QAA, 2006): 
1. Institutional management of academic standards

2. Institutional management of learning opportunities

3. Institutional approach to quality enhancement

4. Collaborative arrangements

5. Institutional arrangements for postgraduate research students

6. Published information

At the academic audit, in England, when the evaluation is finished the process ends with a report that will include recommendations for further consideration by the institution. These recommendations will be categorized as "essential" if the team believes that matters are putting the standards and the quality at risk and require urgent corrective actions, "advisable" if the recommendations refer to matters that have potential to put quality and standards at risk and require preventive action, and finally "desirable" recommendations when they refer to matters that have potential to improve the quality of the institution. (QAA, 2004)

The QAA carries out reviews on behalf of HEFCE and report their findings to these councils but the agency works independently, and HEFCE has no statutory power to change or affect the reviews. The process of academic review continues to comprise an approach focused on the establishment, maintenance and enhancement of academic standards and quality of learning opportunities. On each academic review, the team express their "confidence", "limited confidence" or no "confidence" about the academic standards, and make judgements of "commendable", "approved" and "failing" for the quality of the learning opportunities. (QAA, 2004)

The academic standards evaluated are (QAA, 2004):

1. Aims and Outcomes

a. How well the intended learning outcomes relate to the overall aims of the programme and whether they enable the aims to be met;

b. The extent to which they are aligned with external reference points, including the FHEQ, to provide an appropriate level of challenge to students;

c. The extent to which they are aligned with, and informed by, relevant subject benchmark statements, where appropriate, and any professional or statutory body requirements;

d. How well the intended learning outcomes of a programme and its constituent parts are communicated to staff, students and external examiners/verifiers.

2. Curricula

a. How the college plans the curriculum design and content and how decisions about contributing modules and their sequencing are made; 
b. Whether the design and content of the curricula encourage achievement of the intended learning outcomes in terms of knowledge and understanding, cognitive skills, subject specific kills (including practical/professional skills), transferable skills, progression to employment and/or further study, and personal development;

c. The extent to which curricular content and design are informed by recent developments in techniques of teaching and learning, current research, scholarship or consultancy and by any changes in relevant occupational or professional requirements;

d. How the college ensures that the design and organisation of the curriculum provides appropriate academic and intellectual progression and is effective in promoting student learning and achievement of the intended learning outcomes.

\section{Assessment}

a. The extent to which the overall assessment strategy has an adequate formative function in developing student abilities, assists them in the development of their intellectual skills and enables them to demonstrate achievement of the intended learning outcomes, in both campus and placement settings;

b. The assessment methods chosen and their appropriateness to the nature of the intended learning outcomes and to the type and level of work;

c. The criteria used to enable internal and external examiners/verifiers to distinguish between different categories of achievement, and the way in which criteria are communicated to students;

d. The security, integrity and consistency of the assessment procedures, the setting, marking and moderation of work in both campus and placement settings, and the return of student work with feedback;

e. How employers and other professionals contribute to the development of assessment strategies, where appropriate.

\section{Achievement}

a. The evidence that students' assessed work demonstrates their achievement of the intended learning outcomes;

b. The evidence that standards achieved by learners meet the minimum expectations for the award as measured against the FHEQ and relevant subject benchmark statements, if appropriate;

c. Whether students are prepared effectively for their subsequent employment roles;

d. The levels of achievement indicated by the statistical data, whether there are any significant variations between modules or awards and the successful progression to employment;

e. How the college promotes student retention and achievement.

The learning opportunities evaluated are (QAA, 2004): 


\section{Teaching and Learning}

a. The range and appropriateness of teaching methods employed in relation to curriculum content and programme aims;

b. How staff draws upon their research, scholarship, consultancy or professional activity to inform their teaching;

c. The ways in which participation by students is encouraged and how learning is facilitated;

d. How the materials provided support learning and how students' independent learning is encouraged;

e. Student workloads;

f. How quality of teaching is maintained and enhanced through staff development, peer review of teaching, integration of part-time and visiting staff, team teaching as well as effective induction and mentoring for new staff.

2. Student Progression

a. The effectiveness of arrangements for recruitment, admission and induction and whether these are generally understood by staff and applicants;

b. The overall strategy for academic support and its relationship to the student profile and the overall aims of the programme;

c. How learning is facilitated by academic guidance, feedback and supervisory arrangements;

d. The arrangements for academic tutorial support, their clarity and their communication to staff and students, and how staff is enabled to provide the necessary support to students;

e. The quality of written guidance;

f. The extent to which arrangements are in place and effective in facilitating student progression towards successful completion of their programmes.

\section{Learning Resources}

a. Staffing levels and the suitability of staff qualifications and experience, including teaching and non-teaching staff;

b. Professional updating to keep abreast of emerging and relevant subject knowledge and technologies;

c. Staff development opportunities, including induction and mentoring for new staff, and whether opportunities are taken;

d. Journal and electronic media;

e. Access times and arrangements, and induction and user support provision;

e. Computing hardware, and both general and subject-specific software availability, and currency; 
f. Accessibility, including times of opening and opportunities for remote access, and induction and user-support provision;

g. Specialist accommodation, equipment and consumables;

h. Adequacy, accessibility, induction, user-support and maintenance;

i. Suitability of staff and teaching accommodation in relation to the teaching and learning strategy and the provision of support for students.

The HEFCE receives money from the government to fund all universities. The funds are divided according to a formula that is published and that uses inputs such as the number of students, research quality and volume from research councils, industry and charities. Therefore the HEFCE does not fund teaching provision based on quality as they consider that giving extra funding for better quality would drive the extremes further apart. They rather expect a basic threshold of good quality and standards.

In the UK there are no official rankings between universities, the higher education sector is very diverse and it is very difficult and subjective to rank the institutions. Besides this, several newspapers produce their own rankings using a variety of sources and indicators. However these may not have input or support from the universities.

In 1999 the Performance Indicators Steering Group (PISG) was established by the EHFCE with the support of all funding councils and following the recommendations of the National Committee of Inquiry into Higher Education, with the main objective of developing suitable indicators and benchmarks of performance in the higher education sector (HEFCE, 2004). Since 2002/2003 the Higher Education Statistics Agency (HESA) has published the performance indicators on behalf of the EHFCE and, every year, the PISG oversees the production of these indicators, the development of new indicators, and agree amendments to existing indicators. These performance indicators are composed by statistical ratios intended to offer an objective measure on the performance of the higher education institutions. They currently cover widening participation indicators, non-continuation rates (including projected outcomes), module completion rates, research output and employment of graduates. (HECFE, 2006)

Performance Indicators (HECFE, 2006):

1. The percentage of entrants who attended a school or college in the state sector (young full-time students);

2. The percentage of entrants who were returned with National Statistics socio-economic categories 4 to 7 (young full-time students); 
3. The percentage of entrants whose home area (as denoted by they postcode) is known to have a low proportion of 18 and 19 years-old in higher education (young full-time students);

4. The percentage that come from "low participation" neighbourhoods (young full-time students; mature part-time students);

5. The percentage that come from "low participation" neighbourhoods (mature full-time students);

6. Percentage of disabled students in the sector;

7. Percentage of students not continuing in higher education after first year of entry;

8. Percentage of students returning to higher education after a year out following the year of first entry;

9. Projected outcomes - obtain a degree, leave with no award;

10. Completion rates of part-time students;

11. Employed or studying six months after graduation;

12. PhDs per academic staff costs;

13. Income from research grants and contracts per academic staff costs;

14. PhDs per research funding;

15. Income from research grants and contracts per research funding.

The objectives of producing these indicators are to provide reliable information on the nature and performance of the UK higher education sector, allow comparison between individual institutions of a similar nature, enable institutions to benchmark their own performance, inform about policy developments and contribute to the public accountability of higher education. Because there are such differences between the universities the benchmark should be used in two different ways, first to see how well an institution is performing compared to the higher education system as a whole, and second to decide whether to compare two institutions. (HECFE, 1999)

\section{Regulation of the Quality of the Higher Education in Portugal}

\section{The Current Situation}

The Portuguese higher education system is binary, composed by universities, research oriented, and polytechnics, professionally oriented, and both can be public or private. (OCDE, 2006) Until recently the organization that ensured the quality in higher education was the National Evaluation Council for Higher Education (CNAVES). The evaluation of the educational programmes was per- 
formed by the Evaluation Councils and the main responsibility of CNAVES was to ensure the global coherence of the quality assurance on a comparative study of the evaluation reports. But in November 2006, the European Association for Quality Assurance in Higher Education (ENQA) published a report, a request from the Portuguese government, which criticised the two-tier organisational structure arguing that it was complex and that a certain level of operational inefficiency and inconsistency characterised the organisation. The ENQA panel also pointed a few number of major weaknesses in the Portuguese quality assurance system which include the limited independence of the evaluation councils, the lack of sufficient operational efficiency and consistency, the lack of consequences of the reviews, and finally the reliance on national experts. (ENQA, 2006)

As a consequence of the ENQA report, the Portuguese government ended with the CNAVES activity and created a new agency of evaluation and accreditation in the higher education on the law 369/2007. This law was based on the ENQA recommendations and on the Standards and Guidelines for Quality Assurance in the Higher Education Area (LAW 369/2007). The establishment of a new agency was a specific recommendation of the ENQA report for the new quality assurance system. The law that set the new agency was controversial, especially in the point that referred to the loss of powers of the professional associations. In the future the accreditation power should only be vested on the new national agency. (LAW 367/2007)

\section{The Future Situation}

The recent law 38/2007 provides the standards that should be taken in account to the evaluation made by the new quality assurance agency. This law defines that the higher education institutions should be evaluated through a process that includes a self-assessment report, an external review and a final report. In the final report a decision about the accreditation will be taken based on an evaluation scale.

The standards to measure the quality of the university are divided into two groups. The first group is related to the performance of the higher education institutions. In this group the law has defined the following standards to measure the programmes: teaching quality, staff qualifications, internal quality assurance, research activity, international cooperation, institutional cooperation, organization and management, facilities and equipment, and finally the social support. The second group of standards is connected with the outcomes of the institution activities, like the services to the community, the incomes produced 
by the university, success rates, employment, and public information about the institution and their students work. (LAW 38/2007)

The external assessment leads to a comparison of higher education institutions, schools, or educational programmes. Later the institutions could be ranked. In the future the final decision of accreditation will have three possible consequences, positive, positive but with restrictions, and negative. If the decision is positive with restrictions the higher education institution will have a period of time to follow the recommendations and improve the quality of its programmes. On the other hand, if the decision is negative the institution will not be allowed to keep its programme. (LAW 38/2007)

\section{Some Suggestions for the Future}

The Portuguese higher education system, at this point, does not have any regulation about the quality of its educational programmes. This situation can bring many damages to the country's economy and development. It is urgent to make the new quality assurance agency operational as soon as possible, but not at any price.

The key element of the agency is the independence. If the agency wants to work based on the European Standards the evaluations, the decisions and the follow-up procedure should be totally independent from the government and from the higher education institutions as well. These kinds of organisations, even when independent, are prone to be captured (MARQUES, 2007). Another important issue is the follow-up procedure (OCDE, 2006). Using the system of three categories of accreditation is an important step to improve the quality of the programmes, but the accreditation procedure needs to specify a strong legal framework to protect the Agencies' decisions and the procedures used by the Agency should be coherent and public. The government needs to create instruments to make a clear relationship between the Agency's evaluations and the institutions funding.

The lack of information about the performance of the Portuguese's higher education institutions is slowing down the sector's growth and external investment. We believe that it is imperative for the Portuguese higher education system to have a body that defines what the most important performance indicators are to all the stakeholders and publish them every year, like the performance indicators published by the HESA. With this information the higher education institutions will be more open to all the stakeholders and the students can decide which institution they want to choose for their education based on official information. Performance indicators will enable benchmarking between the 
institutions, with many benefits for the country, especially for the institutions that will become more competitive and improve their quality. This does not mean that the institutions must be ranked, but like the United Kingdom higher education system, the institutions will be able to see how well they are doing in the sector and which areas need more improvement. These statistical data are also an important help for the government to define the policy to adopt for the higher education.

\section{Conclusions}

The regulatory models across Europe are very distinct and are a sign of the culture and of the higher education systems of each country. If we compare Holland, Spain and the United Kingdom we can see that the British system is older than the other ones but it also supplies more information about the institutions performance. The performance indicators published by the HESA are key elements providing information about how well the institutions are doing and a great help for the government to establish its policies.

The Portuguese regulatory model is at this point lagging behind when we look at other countries. In the UK the QAA was established in 1997, the Netherlands created the NAO in 2000 and the Spanish agency ANECA was established in 2002. We can see that the Portuguese Ministry of Science, Technology and Higher Education still has a lot of work to do, but the major step has already been taken. The creation of the quality assurance agency, with the power of evaluation but also of accreditation, which follows the European Standards and Guidelines, will enhance the quality of the Portuguese higher education institutions, and consequently will bring improvements to the economy and help Portugal to achieve broader societal goals in the European context.

\section{References}

ANECA. Institutional assessment guide programme. External assessment guide 2007, Local, 2007.

CPC NETHERLANDS BUREAU FOR ECONOMICS POLICY ANALYSIS. Higher education reform: getting the incentives right, Local, 2002.

ENQA. Quality assurance of higher education in Portugal, Local: 2006.

ENQA. Report of the committee for the review of the accreditation organization of the Netherlands and Flanders, Local:2007. 
ENQA. Report of the panel of the ENQA coordinated review of ANECA, Local, 2006.

FABER, Marike; HUISMAN, Jeroen. Same voyage, different routes? The course of the Netherlands and Denmark to a "European Model" of Quality assurance. In Quality in Higher Education, Local, 2003.

GOSLING, David; D’ANDREA, Vaneest-Marie. Quality development: a new concept for higher education. In Quality in Higher Education, Local, 2001.

HEFCE. Guide: who we are and what we do, 2006.

HEFCE. Performance indicators in higher education, first report of the performance indicators, Local: 1999.

HEFCE. Review of the performance indicators, august 2006, Local: 2006

KANJI, Gopal K; MALEK, Abdul; TAMBI, Bin A. Total quality management in UK higher education institutions. In: Total Quality Management \& Business Excellence, Local, 1999.

LAW n. 369/2007 of 5 November. Diário da República, Local: 2007.

LAW n. 38/2007 of 16 August. Diário da República, Local: 2007.

MARQUES, R. Cunha. Regulação de Serviços Públicos. Local: Edições Sílabo, 2007.

NVAO. Accreditation framework in the Netherlands, Local, 2003.

OCDE. Reviews of national policies for education - tertiary educational. In Portugal, December 2006.

QAA. A brief guide to quality assurance in higher education. Local: 2003.

QAA. Handbook for academic review: England 2004, 2004.

QAA. Handbook for institutional audit: England and Northern Ireland 2006, Local: 2006. 